\title{
NEW THERAPEUTIC APPROACHES FOR THE TREATMENT OF HUNTINGTON'S DISEASE
}

\author{
Yvona Mazurová \\ Charles University in Prague, Faculty of Medicine in Hradec Králové: Department of Histology and Embryology
}

\begin{abstract}
Summary: The use of transplantation (TR) of fetal neural tissue as a therapeutic method started much later in patients suffering from Huntington's disease (HD) than in those with Parkinson's disease. The clinical trial, following a wide range of animal experiments (neurotoxic models and newly also transgenic mice), includes about 30 HD patients until now. Because of limited use of the human fetal tissue by ethical and technical concerns, there is necessity to search for the alternative sources for neural grafting. The first attempt with xenotransplantation (in 12 HD patients) and with TR of encapsulated genetically modified cells (in 6 HD patients) was performed, but no appreciable improvement of status in any of those patients was noted. Since no effective pharmacological treatment of HD is available, the TR of fetal neural tissue is now the only therapeutic approach which provides a reduction of symptoms in most of grafted patients. The possibilities are enormous offered by neural stem cells, optionally by embryonic stem cells, which could be expanded in cultures, cloned or genetically modified and then grafted into the patient's brain. On the other hand, the neural progenitor and stem cells, normally present within the subependymal layer of the lateral brain ventricles also in adulthood, might be induced to become an endogenous source of glia and neurons participating in the brain's repair.
\end{abstract}

Key words: Huntington's disease; Neural transplantation; Clinical trials; Animal models; Fetal neural tissue; Xenotransplantation; Encapsulated genetically modified cells; Neural stem cells; Subependymal layer

\section{Introduction}

Huntington's disease (HD) is an inherited neurodegenerative disorder, first described by Dr. George Huntington in 1872 (35). Compared with Parkinson's disease (PD), its incidence (5-10 patients per 100000 inhabitants - 61) is lower, but since no effective treatment is available, HD is always lethal in a relatively short time (10-15 years) - its social relevance is therefore considerable.

In 1993, the "Huntington's Disease Collaborative Research Group" (36) discovered the genetic defect at the IT15 gene locus at the short arm of chromosome 4 (found in $1983-31)$. This genetic defect results in an increased number of polyglutamine encoding CAG repeats at the site encoding for the protein named huntingtin. An abnormal form of huntingtin, which usually contains 40 or more CAG repeats (occasionally even 36 repeats) causes the development of HD (46). Seriousness of HD is directly proportional to the number of repetitions (e.g. 60 and more repetitions usually denotes a juvenile form of HD with a rapid progression). But neither of these discoveries has led to any progress in HD therapy yet.

Degeneration of the brain basal ganglia (and later, also of the cortex) is accompanied by movement disorders (chorea, dyskinese), cognitive problems (dementia) and beha- vioral changes (rapid mood swings, depression, etc.). Histopathologically, HD is characterized by programmed premature death particularly of medium-sized spiny striatal neurons (in the caudate nucleus and putamen), e.g. by the impairment and loss of mainly GABA-ergic neurons which provide inhibitory innervation to globus pallidus and substantia nigra (pars reticularis) - (e.g. 65, 39). It has been suggested that the neuronal death occurring in HD is related to an underlying slow endogenous excitotoxic process (1) or to mitochondrial dysfunction (11). Recently, CAG expansion has been shown to activate caspase-8, a known trigger of apoptotic cell death (59); however, the specific mechanism by which the CAG expansion damages and ultimately destroys neurons remains unknown.

\section{Animal models}

Intrastriatal administration of neurotoxic acids serves as the most frequent animal model of HD. Formerly the kainic acid was used (the first animal model of HD was performed in 1976 - 16), later ibotenic acid (e.g. 37) and subsequently quinolinic acid $(9,49)$. Another model which utilize the mitochondrial toxin 3-nitropropionic acid (3-NP) to produce HD-like striatal lesion (e.g. 10) is only rarely used. 
Animal models have allowed extensive research into therapeutic strategies for HD: (a) pharmacological strategy - e.g. replacement of the transmitter, (b) surgical strategy replacement of degenerated neural tissue by neural graft. The first strategy, i.e. pharmacotherapy is difficult because of the extent and complexity of the damage to the brain functions. Recently, the systemic administration of glutamate antagonist (riluzole) has been under clinical investigation and the obtained data suggests that it may be effective in the symptomatic treatment of chorea in HD patients, but its role in slowing the disease process is unclear (56). On the other hand, a large body of the papers related to the neural transplantation in animal models (of HD as well as PD) have convincingly demonstrated that grafted tissue (mostly of the ventral mesencephalon/striatum) integrates well with the lesioned host brain tissue and improves motor, and partly also cognitive functions (e.g. 14). The first transplantation of fetal striatum into the kainic acid-lesioned rat brain was carried out in 1983 (18). Even though animal neurotoxic models of HD are not fully equivalent to HD in humans, which is a bilateral, progressive disease, associated with multiple degeneration, they allow us study different capabilities of the fetal neural graft and conditions important for successful neural transplantation.

Recently, the hemizygote transgenic mice (with expanded CAG repeats at IT15 locus of HD gene) exhibit progressive neurological phenotype similar to the motor symptoms of HD (8). Surprisingly, the effect of intrastriatal neural grafting in these transgenic animals is not similar to that into the neurotoxic lesion. Although these grafts were seen to survive and normally differentiate within the host striatum, their behavioral effects were only small, particularly on the profound neurological deficiency of the transgenic mice (19).

\section{Neural transplantation in Huntington's diseased patients}

The encouraging results of animal experiments, obtained during nearly 20 years, and the absence of pharmacotherapy have initiated the clinical trials of fetal neural tissue grafting.

In 1994, the "European Network for Striatal Transplantation in Huntington's Disease" - NEST-HD (equivalent to NECTAR group for transplantation in Parkinson's diseased patients) was established, and later the European register of HD patients was also created. The lack of consistent evaluation in these first patients has led to the development of standardized evaluation tests of HD patients prior to and following grafting - Core Assessment for Intracerebral Transplantation in Huntington's Disease (CAPIT-HD) protocol (55), and Unified Huntington's Disease Rating Scale (UHDRS) scoring; neuropsychometric testing is also carried out. For non-invasive in vivo evaluation (detection and quantification) of transplant function (regional changes in metabolism and blood flow within the brain etc.) the PET (Positron Emission Tomography) or SPECT (Single Photon Emission Computer Tomography) and/or MRI (Magnetic Resonance Imaging) are used repeatedly particularly following surgery (e.g. 54, 4, 57).

The first neural transplantation in a HD patients performed by Madrazo in $1990(47,48)$ and, surprisingly, also in Czechoslovakia by Šramka in 1991 (64) was indeed only experimental. After an interval that lasted several years, a new wave of transplantation in a larger number of patients suffering from HD began in 1996.

In 1966 and 1997, the group headed by Dr. O. Kopyov from the Neuroscience Institute at the Good Samaritan Hospital, Los Angeles, performed the transplantation of fetal mesencephalic tissue on ten patients (20) and then on a further three HD patients $(54,38,57)$. Each patient received bilateral grafts of lateral ganglionic eminence from five to eight donors, placed into the caudate nucleus (one graft on each side) and the putamen (four grafts on each side). All patients were evaluated using the UHDRS, neuropsychological tests and MRI three months prior to, and six months up to a year after the surgery. Cyclosporin immunosuppression was also carried out. Seven of all grafted patients demonstrated the strong improvement in their HD symptoms; in 2 patients there was a moderate improvement (30-50\% on UHDRS score), in 3 of the patients only a mild improvement (20-30\% on UHDRS score), and in one patient, who had a cerebral hemorrhage which was removed, there was no improvement observed during the three month post-operative period .

A neural transplant program was also initiated at the University of South Florida in 1998 (27,28,33). Seven patients underwent bilateral stereotactic transplantation of the fetal mesencephalic tissue (far-lateral ventricular eminence) from donors aged 7.5-9 weeks; subjects received 2-8 striata per side placed into the caudate and putamen. Cyclosporin was administrated 2 weeks before and 6 months post surgery. Patients were evaluated using UHDRS scoring and neuropsychometric testing every 3 months for 12 months prior to and up to 2 years post surgery. PET scan evaluation was also used. The improvement was evident in four patients, only mild in 2 patients (in one of them developed subdural hematoma which was removed without complication), and the state escalated in one patient who experienced bilateral subdural hematoma - clinical status improved following evacuation of hematoma but never returned to baseline. One patient died 18 months after transplantation from a myocardial event. Histological analysis demonstrated well developed grafts that partially filled the diseased striatum; tyrosine hydroxylase-positive host nerve fibers grew into the striatal-like patches of neurons within the graft (29).

Concurrently, in France (at the Faculty of Medicine in Creteil) the group headed by Dr. A. Bachoud-Levi and Dr. M. Peschanski also began neural transplantation in HD patients $(52,6,7)$. Five patients were followed-up according to the above-mentioned protocol at least 2 years before and 
a year post grafting. They were grafted with a suspension of the human fetal neuroblasts into the right striatum then, after a year, into the left striatum. The PET and MRI scans confirmed the viability of transplants in three patients up to a year post surgery. Accordingly, motor and cognitive functions were improved in these patients, but not in the other two patients. In this case, the cell suspension of cultured neuroblasts (i.e. without the glial cells) was only used for grafting. In comparison with small pieces of the fetal brain tissue, which were usually grafted, the cultured cells suspension represents more available and also more selective (e.g. composed of neurons only) grafts. However, in contrast to the experimental results (e.g. 13, 58) cell suspension grafts, particularly composed of cultured neurons only, placed in to human brain gave worse results in relation to the restriction of behavioral impairment of patients.

In spite of these encouraging results that have shown the justification and clinical applications of neural transplantation in HD patients, there is a necessity to seek for the alternative sources for neural grafting because of limited use of the human fetal tissue by ethical and technical concerns (above all with collection of an appropriate number of grafts for every one patient). Recently, due to these requests, the transplantation of porcine fetal neural cells (xenotransplantation) and encapsulated cells engineered to secrete trophic factors were carried out in the HD patients, also.

Xenotransplantation of the fetal porcine striatum was performed in twelve (60) and then in ten PD patients (23) but also in twelve patients suffering from HD (23). The cell suspension (up to 24 million cells) derived from lateral ventrical eminence was grafted unilaterally in HD patients with moderate motor symptoms. Half of these patients underwent the cyclosporine immunosuppression, the remaining patients were grafted with immune-modulated (against MHC I) fetal porcine cells. However, in comparison with mild to moderate improvement in most of the grafted PD patients, there was no observed appreciable improvement of status in any of these HD patients up to a year post surgery.

The capacity for neuroprotection of striatal neurons was demonstrated in various animal models for several neurotrophic factors (e.g. 3, 21). It includes also the ciliary neurotrophic factor (CTNF). It has been suggest that neurotrophic factors may be able to slow down the disease progression by reactivating the degenerating cell's synthetic machinery which produces proteins that are essential for cell maintenance and survival (34). The delivery of neurotrophic factor must be (1) as close to the target as possible, (2) continuous, and (3) long-lasting. The most promising, in relation to these mentioned conditions, appears to be the application of encapsulated genetically modified non-neuronal cells or immortalized lines of neural stem cells (as a producers of dopamin for the transplantation in PD patients). An ex vivo gene therapy approach based on encapsulated genetically modified Baby Hamster Kidney (BHK) cells will be used for the continuous and long-term (at least 6 months) intracerebral delivery of human CTNF. An attempt with grafting of encapsulated BHK-hCNTF cells (up to 106 cells surrounded by a semipermeable membrane) into the right cerebral ventricle has been done in six HD patients (7). The status evaluation of these patients has not been published yet.

In comparison with Parkinson's disease, where the safety for neural transplantation was demonstrated in many patients (e.g. 43, 25, 62, 51, 26, 66, 32), the neural grafting in HD patients has advanced only now, but these preliminary results are encouraging. Although HD and PD are both extrapyramidal movement disorders the extent of the brain damage is completely different. The essential lesion of PD involves progressive degeneration of dopamine-containing neurons in pars compacta of the substantia nigra, resulting in a loss of dopaminergic input to the striatum. Therefore the long-lasting substitution of dopamin and some other substances, produced by fetal mesencephalic tissue grafted into undamaged striatum, appears to be adequate therapy in PD patients. On the other hand, in HD patients the partial necrosis (selective degeneration of the striatal neurons), followed by atrophy and subsequent gliosis within the striatum (but also in cortex and some other brain regions) represents very complex terrain for the fetal neural graft outgrowth. The typical symptoms of HD (severe impairments in both motor and cognitive functions) results from the loss of inhibitory connections in the corticostriatopallidal circuit. Hypothesis suggests that neural graft (particular of the fetal mesencephalic tissue) would be capable, at least partly, to reinstate inhibitory GABA-ergic control of the pallidal output neurons resulting in alleviation of the abovementioned impairments.

\section{New approaches in neurotransplantion research}

Except the both of latter therapeutic strategies, i.e. xenotransplantation and neuroprotection, in which the potentials and applications have not been satisfactory clarified yet on the experimental level, the other alternative sources for the neural grafting are continually sought.

It would be of enormous benefit if human neural tissue could be generated in vitro. It has been now established that pluripotent embryonic stem (ES) cells from the mouse blastocyst can be propagated in culture and differentiated into a range of tissues, including neuronal and glial cells. In other studies, more-restricted neural stem cells have been isolated from both the developing and adult rodent brain (63).

A large number of papers are focused on the transplantation of neural stem or progenitor cells cultured from embryonic subventricular zone (SVZ) or from the same region - subependymal layer (SEL) or subventricular layer/zone (SEL/SEZ) of lateral brain ventricles - in adult individuals (e.g. 24, 45, 5). During the embryonic period, SVZ delaminates from the ventricular zone (therefore this term 
should not be used in adult individuals); it is most prominent in primordia of basal ganglia (e.g. 22). During the development, the SVZ generates cells destined not only for the adjacent basal ganglia (50) but also for structures in the forebrain, including the diencephalon (41) and cortex (17). In the postnatal period and also in adulthood, it is defined as a secondary (postnatal) proliferative region underlying the ependymal layer in the forebrain of all mammals, including the human (e.g. 30).

However, if the SEL contains the largest concentration of dividing cells in the mature brain, it might be also induced to become an endogenous source of glia and neurons participating in brain repair. Continuous neurogenesis was clearly demonstrated in two brain regions only: (a) in SEL of the lateral walls of lateral cerebral ventricles, from where (particularly from the most rostral part) newborn cells migrate along the defined pathway called rostral migratory stream - RMS, (b) to the olfactory bulb, where they differentiate into new interneurons (44), (c) in the subgranular layer of the dentate gyrus of the hippocampus, the site of origin of the granular cells of the dentate gyrus (40). Neurogenesis in SEL in relation to other brain regions has not been proved yet. We do not know, however, whether these new cells are capable to reconstruct fully functional neuronal circuits (14) and whether the precursors in embryonic and adult SEL are equivalent. It was proved that the postnatal SEL is chiefly the site of gliogenesis, i.e. generation of new astrocytes and oligodendrocytes (e.g. 42).

\section{Conclunsion}

HD is a fatal disorder with unremitting progression, the treatment of which is only palliative in comparison to PD where alternative pharmacological and surgical therapies are available. Therefore, the risk associated with trials of neutral transplantation in HD patients is more reasonable in relation to potential benefits than similar trial in patients with PD. Following the experimental results and clinical trials it is proven that fetal neural transplant within the brain of HD patients (1) can survive for a relatively long time, (2) is not affected by neurodegenerative process which destroys striatum, and (3) HD gene is not carried within the neural graft. Even though views concerning the justification of clinical application of neural grafting in HD patients are not uniform (e.g. 15, 53, 12), it is presently the only available method to reduce at least the consequences of the devastating neurodegenerative disorder and to slowing down its progression. However, it is necessary to carry out further investigations to extend our knowledge concerning neural graft abilities, the new sources of tissues (xenotransplantation) or cells for grafting - neural stem or progenitor cells, genetically engineered non-neural cells etc. It must be stressed that the stem cell transplantation and gene transfer for in vivo or ex vivo modification of either non-neuronal cells or neural cells are conceptually different from the use of primary neuronal fetal human tissue. With the aid of cell cultures, we are able to attain a quantitative amount of information just by experiments in vitro. However, because of complicated microenvironment of the CNS it is necessary to finish these experiments by their application in vivo.

In contrast to other neurodegenerative diseases such as PD or Alzheimer's disease, genetic testing can positively identify those individuals who are predestined to develop HD prior to the development of extensive neuropathological and clinical symptoms. Therefore, there is an opportunity in the future to delay or diminish clinical symptoms by developing effective neuroprotective strategies for HD patients. Many additional studies need to verify all these abovementioned possibilities.

\section{Acknowledgments}

The author thanks Ms. Ellesse Lomas for the proof of the English version of this manuscript. This work is supported by the Grant (NF 5400-3) of the Ministry of Health of the Czech Republic.

\section{References}

1. Albin R, Greenamyre JT. Alternative excitotoxic hypotheses Neurology 1992;42: 733-8.

2. Altman J. Autoradiographic and histological studies of postnatal neurogenesis IV. Cell proliferation and migration in the anterior forebrain, with special reference to persisting neurogenesis in the olfactory bulb. J Comp Neurol 1969;137:433-58

3. Anderson KD, Panayotatos N, Corcoran TI, Lindsay RM, Wiegan SJ. Ciliary neurotrophic factor protects striatal output neurons in an animal model of Huntington's disease. Proc Natl Acad Sci USA 1996;93:7346-51.

4. Andrews TC, Weeks RA, Turjanski $\mathbf{N}$ et al. Huntington's disease progression: PET and clinical observations. Brain 1999;122:2353-63.

5. Armstrong RE, Svendsen CN. Neural stem cells: from cell biology to cell replacement. Cell Transpl 2000;9:139-52.

6. Bachoud-Levi A, Bourdet C, Brugieres P et al. Safety and tolerability assessment of intrastriatal neural allografts in five patients with Huntington's disease. Exp Neurol 2000a; 161(1):194-202

7. Bachoud-Levi AC, Deglon N, Nguyen JP et al. Neuroprotective gene therapy for Huntington's disease using a polymer encapsulated BHK cell line engineered to secrete human CNTF. Hum Gene Ther 2000b;11(12):1723-9.

8. Bates GP, Mangiarini L, Mahal A, Davies SW. Transgenic models of Huntington's disease. Hum Molec Genet 1997;6:1633-7.

9. Beal MF, Kowall NW, Ellison DW, Mazurek MF, Schwartz KJ Martin JB. Replication of the neurochemical characteristics of Huntington's disease by quinolinic acid. Nature 1986;321:168-71.

10. Beal MF, Brouillet E, Jenkins BG et al. Neurochemical and histologic characterization of striatal excitotoxic lesions produced by the mitochondrial toxin 3-nitropropionic acid. J Neurosci 1993;13(10):4181-92.

11. Beal MF. Aging, energy and oxidative stress in neurodegenerative diseases. Ann Neurol 1995;38:357-66.

12. Beal MF, Hantraye P. Novel therapies in the research for a cure for Huntington's disease. Proc Natl Acad Sci 2001;98(1):3-4.

13. Björklund A, Stenevi U, Schmidt RH, Dunnett SB and Gage FH. Intracerebral grafting of neuronal cell suspensions. Acta Physiol Scand Suppl 1983;522:1-75.

14. Björklund A, Lindvall O. Cell replacement therapies for central nervous system disorders. Nature Neurosci 2000;3 (6):537-44

15. Brundin P, Fricker RA, Nakao N. Paucity of P-zones in striatal grafts prohibit commencement of clinical trials in Huntington's disease. Neuroscience 1996;71(3):895-7.

16. Coyle JT, Schwarcz R. Lesion of striatal neurones with kainic acid provides a model for Huntington's chorea. Nature 1976;263(5574):244-6.

17. De Carlos JA, Lopez-Mascaraque L, Valverde F. Dynamics of cell migration from the lateral ganglionic eminence in the rat. J Neurosci 1996;16:6146-56.

18. Deckel AW, Robinson RG, Coyle JT, Sanberg P. Reversal of long-term locomotor abnormalities in the kainic acid rat model of Huntington's disease by day 18 fetal striatal implants. Eur J Pharmacol 1983;93(3-4):287-8.

19. Dunnett SB, Carter RJ, Watts C et al. Striatal transplantation in a transgenic mouse model of Huntington's disease. Exp Neurol 1998;154(1):31-40. 
20. Eagle KS, Kopyov OV. Early postoperative results in ten Huntington's disease patients following transplantation of foetal striatal tissue.

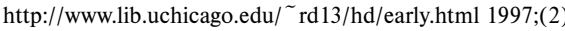

21. Emerich DF, Winn SR, Hantraye PM et al. Protective effect of encapsulated cells producing neurotrophic factor CNTF in a monkey model of Huntington's disease. Nature 1997;386:395-9.

22. Fentress JC, Stanfield BB, Cowan WM. Observations on the development of the striatum in mice and rats. Anat Embryol 1981;163:275-98.

23. Fink JS, Schumacher JM, Ellias SL et al. Porcine xenografts in Parkinson's disease and Huntington's disease patients: preliminary results. Cell Transplant 2000;9(2):273-8

24. Fisher LJ. Neural precursor cells: applications for the study and repair of the central nervous system. Neurobiol Dis 1997;4:1-22.

25. Freed CR, Breeze RE, Rosenberg NL et al. Survival of implanted fetal dopamine cells and neurologic improvement 12 to 46 months after transplantation for Parkinson's disease. N Engl J Med 1992;327(22):1549-55.

26. Freeman TB, Olanow CW, Hauser RA et al. Bilateral fetal nigral transplantation into the postcommissural putamen in Parkinson's disease. Ann Neuro 1995;38(3):379-88.

27. Freeman TB, Olanow CW, Hauser RA et al. Human fetal tissue transplantation for the treatment of movement disorders. In: Germano IM ed. Neurosurgical Treatment of Movement Disorders. New York: AANS Publications, 1998:177-92.

28. Freeman TB, Hauser RA, Sanberg PR, Saporta S. Neural transplantation for the treatment of Huntington's disease. Prog Brain Res 2000a;127:405-11.

29. Freeman TB. Transplanted fetal striatum in Huntington's disease: phenotypic development and lack of pathology. Proc Natl Acd Sci 2000b; 97(25):13877-82.

30. Frisén J, Johansson CB, Lothian C, Lendahl U. Central nervous system stem cells in the embryo and adult. Cell Mol Life Sci 1998;54(9):935-45.

31. Gusella JF, Wexler NS, Conneally PM et al. A polymorphic DNA marker generally linked to Huntington's disease . Nature 1983;306(5940):234-8.

32. Hauser RA, Freeman TB, Snow BJ et al. Long-term evaluation of bilateral feta nigral transplantation in Parkinson disease. Arch Neurol 1999;56(2):179-87.

33. Hauser RA, Stoessl JA, Eichler SR et al. Pilot evaluation of human fetal striatal transplantation in Huntington's disease. Neurology 2000;54(Suppl 3):A153.

34. Hefti F. Neurotrophic factor therapy for nervous system degenerative diseases. J Neurobiol 1994;25(11):1418-35.

35. Huntington G. On chorea. Med Surg Rep 1872;26:317-21.

36. Huntington's Disease Collaborative Research Group: A novel gene containing a trinucleotide repeat that is expanded and unstable on Huntington's disease chromosomes. Cell 1993;72:971-83.

37. Isacson $\mathrm{O}$, Brundin $\mathrm{P}$, Gage FH, Björklund A. Neural grafting in a rat model of Huntington's disease: Progressive neurochemical changes after neostriatal ibotenate lesions and striatal tissue grafting. Neuroscience 1985;16:799 - 817.

38. Kopyov OV, Jacques S, Lieberman A, Duma CM, Eagle KS. Safety of intrastriatal neurotransplantation for Huntington's disease patients. Exp Neurol 1998;149(1):97-108

39. Kowall NW, Ferrante RJ and Martin JB. Pattern of cell loss in Huntington's disease. Trends Neurosci 1987;10:24-9.

40. Kuhn HG, Dickinson-Anson H, Gage FH. Neurogenesis in the dentate gyrus of the adult rat: age-related decrease of neuronal progenitor proliferation. J Neurosci 1996; 16:2027-33

41. Letinic K, Kostovic I. Transient fetal structure, the gangliothalamic body, connects telencephalic germinal zone with all thalamic regions in the developing human brain. J Comp Neurol 1997;384:373-95.

42. Levison SW, Goldman JE. Both oligodendrocytes and astrocytes develop from progenitors subventricular zone of postnatal rat forebrain. Neuron 1993;10:201-12.

43. Lindvall $\mathrm{O}$, Brundin $\mathrm{P}$, Widner $\mathrm{H}$ et al. Grafts of fetal dopamine neurons survive and improve motor function in Parkinson's disease. Science 1990;247(4942):574-7.

44. Lois C, Alvarez-Buylla A. Long-distance neuronal migration in the adult mammalian brain. Science 1994;264:1145-48.

45. Lundberg C, Martinez-Serrano A, Cattaneo E, Mc Kay RD, Björklund A Survival, integration, and differentiation of neural stem cell lines after transplantation to the adult rat striatum. Exp Neurol 1997;145:342 - 60.

46. MacDonald M.E, Gusella JF: Huntington's disease: translating a CAG repea into a pathogenic mechanism. Curr Opin Neurobiol 1996;6(5):638-43.

47. Madrazo I, Franco-Bourland RE, Cuevas $\mathrm{C}$ et al. Fetal neural grafting for the treatment of Huntington's disease (HD) - report of the first case. Soc Neurosci Abstr 1991;17:902

48. Madrazo I, Franco-Bourland RE, Castrejon H, Cuevas C, Ostrosky-Solis F. Fetal striatal homotransplantation for Huntington's disease: first two case reports. Neurol Res 1995;17(4):312-15.
49. Nakao N, Brundin P. Effects of alpha-phenyl-tetra-butyl nitrone on neuronal survival and motor function following intrastriatal injections of quinolinate or 3nitropropionic acid. Neuroscience 1997;76(3):749-61.

50. Olsson M, Björklund A, Campbell K, Turnbull K. Early specification of striatal projection neurons and interneuronal subtypes in the lateral and medial ganglionic eminence. Neuroscience 1998;84:867-76.

51. Peschanski M, Defer G, N'Guyen JP et al. Bilateral motor improvement and alteration of L-dopa effect in two patients with Parkinson's disease following intrastriatal transplantation of foetal ventral mesencephalon. Brain 1994;117(Pt 3): 487-99.

52. Peschanski M, Césaro P, Hantraye P. Rationale for intrastriatal grafting of striatal neuroblasts in patients with Huntington's disease. Neuroscience 1995;68(2): 273-85.

53. Peschanski M, Césaro P, Hantraye P. What is needed versus what would be interesting to know before undertaking neural transplantation in patients with Huntington's disease. Neurosci 1996;71(3):899-900.

54. Philpott LM, Kopyov OV, Lee AJ et al. Neuropsychological functioning following fetal striatal transplantation in Huntington's chorea: Three case presentations. Cell Transplant 1997;6(3):203-12.

55. Quinn N, Brown R, Craufurd D et al. Core Assessment Program for Intracerebral Transplantation in Huntington's Disease (CAPIT-HD). Mov Disord 1996;11(2): 143-50.

56. Rosas HD, Koroshetz WJ, Jenkins BG et al. Riluzole therapy in Huntington's disease. Mov Disord 1999;140:326-30.

57. Ross BD, Hoang TQ, Bluml S et al. In vivo magnetic resonance spectroscopy of human fetal neural transplants. NMR Biomed 1999;12(4):221-36.

58. Sanberg PR, Cesario V, Borlongan KW, Isacson O. Fetal-tissue transplantation for Huntington's disease: Preclinical studies. In: Freeman TB, Widner H, eds. Cell transplantation for neurological disorders: Toward reconstruction of human central nervous system. Totowa, NJ: Humana Press, 1998:77-93.

59. Sanchez I, Xu CJ, Juo P, Kakizaka A, Blenis J, Yuan J. Caspase-8 is required for cell death induced by expanded polyglutamine repeats. Neuron 1999;22: 623-633.

60. Schumacher JM, Ellias SA, Palmer EP et al. Transplantation of embryonic porcine mesencephalic tissue in patients with PD. Neurology 2000;54:1042-50.

61. Shoulson I. Huntington's disease. In: McKhann AA, McDonald WI, eds. Diseases of the Nervous System. Clinical Neurobiology. Philadelphia: WB Saunders, 1992:1159-68

62. Spencer DD, Robbins RJ, Naftolin F et al. Unilateral transplantation of human fetal mesencephalic tissue into the caudate nucleus of patients with Parkinson's disease. N Engl J Med 1992;327(22):1541-8.

63. Svendsen CN, Smith AG. New prospects for human stem-cell therapy in the nervous system. Trends Neurosci 1999;22(8):357-64

64. Šramka M, Rattaj M, Molina H, Vojtassak J, Belan V, Ružický E. Stereotactic technique and pathophysiological mechanisms of neurotransplantation in Huntington's chorea. Stereotact Funct Neurosurg 1992;58(1-4):79-83.

65. Vonsattel JP, Myers RH, Stevens TJ, Ferrante RJ, Bird ED, Richardson EPJ. Neuropathological classification of Huntington's disease. J Neuropathol Exp Neurol 1985;44:559-77.

66. Widner H. The Lund transplant program for Parkinson's disease and patients with MPTP-induced parkinsonism. In: Freeman TB, Widner H, eds. Cell transplantation for neurological disorders: Toward reconstruction of the central nervous system. Totowa, NJ: Humana Press, 1998:1-18.

Submitted October 2001.

Accepted November 2001.

Doc. MUDr. Yvona Mazurová, CSc., Charles University in Prague,

Faculty of Medicine in Hradci Králové,

Department of Histology and Embryology,

Šimkova 870, 50001 Hradec Králové,

Czech Republic.

e-mail: mazurova@lfhk.cuni.cz 